\title{
A Study on Job Enrichment and Individual Performance among Faculties with Special Reference to a Private University
}

\author{
M. Venith Vijay \\ Research Associate, VIT Business School, VIT University, Vellore, Tamilnadu, India \\ Email: venithvijaym@vit.ac.in \\ Dr. R. Indradevi \\ Associate Professor, VIT Business School, VIT University, Vellore, Tamilnadu, India \\ Email: rindradevi@vit.ac.in
}

Doi:10.5901/mjss.2015.v6n1p252

\begin{abstract}
Job enrichment is one of the cherished goals to achieve individual performance. It is essential to understand how job enrichment is a valuable tool for managing and fostering the successful employee performance. Enriched job consists of various elements like task significance, task identity and skill variety which improves the performance of employees and motivates them to perform zealously. This study intends to focus on the relationship between job enrichment and individual performance. A quantitative research is employed to explore the factors of job enrichment (Task Significance, Task Identity \& Skill Variety) on individual performance in education institution. Data was collected from the faculties in private university using probability stratified random sampling techniques to measure the relationship between the three factors towards individual performance. An empirical evidence from the exploratory study is presented which identified that the second factor contributes more on enhancing the performance of the individuals. Further research can be conducted on other factors of job enrichment and their impact on individual performance of the employees in education institution.
\end{abstract}

Keywords: Job enrichment, Individual performance, Task significance, Task identity, Skill variety.

\section{Introduction}

Job enrichment analyzed the various assumptions inherent in the job enrichment approach, along with the ramifications and utility of employing it in work organizations. This article suggested that the utility of job enrichment programs predicted on the development of increasing intrinsic job elements and down-grading attention to extrinsic factors, is questionable, at best. Kaplan et al (1969).

Job enrichment adds a feeling of satisfaction derived from work itself. Structured jobs make people feel like human beings rather than units of production and that the pressures arising from the obvious discrepancies between social and technological changes are reduced Walsh (1974).

There is interdependence between job enrichment, job enlargement, employees' satisfaction and employee's performance. Job enrichment and job enlargement made the employees' feel that the organization actually owns them and thus improved their performance. Employees' performance can be enhanced by increasing their satisfaction level and satisfaction level can be enhanced by enriching and enlarging their jobs in the organization Saleem et al (2012).

The job enrichment enhances the motivation level and the performance of the employees on the work place and their propensity to achieve the goals is also becomes more possible (Bryan \& Locke, 1967; Latham \& Baldes, 1975; Latham \& Kinne, 1974; Latham \& Yukl, 1975; Ronan, Latham, \& Kinne, 1973; Herzberg \& Frederick, 1968; Myers, 1970; Raja, 1974).

\section{Literature Review}

\subsection{Job Enrichment}

Norton et al. (1979) evaluated whether or not job enrichment had taken place and examined the conditions under which it was likely to be a success or a failure. The paper also studied the evolution of the term 'job enrichment'; contrast job 
enrichment to other organizational change methodologies; examined the most widely used measures of job content and job satisfaction; offered a paradigm for research on job enrichment; discussed two major reviews of job enrichment - one critical and one supportive and suggested conditions which research may show to be related to the success of job enrichment programs.

McLean and Sims (1978) in their article on job enrichment from theoretical poverty considered various definitions of the concept of job enrichment and considered the findings of job enrichment studies. The article also illustrated some shortcomings in the theory and its applications and summarized these shortcomings so that instead of remaining isolated and incomprehensible failures they point to areas of deficiency. The research evidence suggested that a more promising line for the practitioner would be the development of an approach which enables them to discover directly from the employees themselves the meaning that their work has for them, their aspirations in work and the forms of satisfaction which they do and do not hope to gain from it. They concluded that only such a 'redesigned' approach to choosing and making the changes involved can ever lead to predictable, successful job redesign.

King-Taylor (1977) in her article on job enrichment and motivation suggested that jobs must be revised to meet the needs and fulfill the aspirations of people as individuals, not as robots. The author insisted that a program of job enrichment should usually begin by defining the jobs which had to be done and which were affected by the programme; a project team comprising representatives of the task holders should be formed to do this. According to the author, 'brainstorming' sessions during which the people involved in the jobs suggest as many changes as possible, could conceivably make them more challenging and interesting, as well as more efficient and productive. According to the author, job enrichment is not a technique, but a way of managing which is married into the company philosophy and organizational structure - job enrichment is in essence, true participation and worker involvement.

Collins and Raubolt (1975) examined the association between employee background and occupational characteristics and degree of resistance to a job enrichment programe in a large-scale manufacturing firm. The study group consisted of engineers, engineering associates and draftsmen. The questionnaire included background and occupational characteristics such as age, education, position and tenure. The findings revealed that education was the most important determinant of degree of resistance. Employees with a college degree were found to be less resistant to job enrichment than were employees without a degree. Other important determinants found were age and task performed, revealed that more youthful employees were non-resistant than older employees and more employees who were performing similar tasks were non-resistant than were employees performing general tasks. The study also revealed other characteristics with resistance to job enrichment such as the number of years to retirement.

Werther (1975) stated that employment enrichment views the total work enrichment confronting employees as a system which consists of two overlapping areas: the worker-job subsystem and the worker-organization subsystem. According to him, the purpose of job enrichment is to improve the worker-job relationship. Job enrichment addresses itself primarily to one dimension of the employment relationship: the worker-job aspect represents the most significant component of the employee's connection with the organization. He argued that without changes in the overall workerorganization relationship, employees were apt to believe job enrichment is manipulative. Moreover, the author pointed out that the removal of the more dehumanizing characteristics of the job causes the employee-organization interface to increase in importance - the worker becomes more sensitized to the negative aspects of his association since there were fewer unpleasant distractions in connection with the job.

\subsubsection{Factors of Job Enrichment}

The following three job features are considered in the model; task significance, task identity and Skill variety which is defined as formulated in Hackman \& Oldham (1975).

\subsubsection{Task Significance}

Work that has a direct impact on the organization or its stakeholders. It indicates that worker should consider that they are doing something in their organization and or society.

\subsubsection{Task Identity}

Facilitating people to carry out a complete piece of work. When the task is widened to produce an entire product then the task identity recognized. 


\subsubsection{Skill Variety}

Increasing the number of skills that individual employ while performing work. Variety provides employees a greater sense of capability as they can perform various kinds of works in different ways.

\subsection{Individual Performance}

In current era employee performance has been into a lot of debates among the industrialist and researchers. Employee performance within an organization can be defined with a variety of ways including their behavior, attitude and motivation to achieve goals (Ali and Jadoon, 2012). Taylor was one of the initial providers who had recognized the factors that are going to influence the performance of the employee during the work and in overall development. There are 4 major factors that may affect the employee performance. These are:

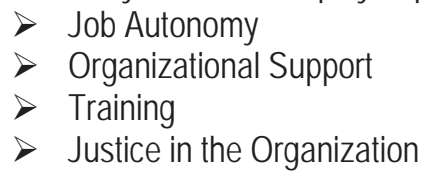

\subsubsection{Job Autonomy}

Job autonomy can play a vital role in enhancing the performance of the employee in the organization. Job autonomy creates a sense of responsibility among the employees (Dean, Colarelli \& Konstans, 1987). Increasing impact of job autonomy on the employee performance and the absence of job autonomy in the organizations creates so many problems like decrease in productivity, performance and increase in stress. The employee performance cannot be increased merely by increasing the focus on the authority, discipline and control in the organizations (Hart \&Willower, 1994).

\subsubsection{Organizational Support and Performance}

The sense of ownership in the organization that the company is giving importance their views and giving them importance is collectively called as organizational support and the existence of that also increase the employee performance (Fasolo, Eisenberger \& Davis LaMastr, 1990). The employees can give extra ordinary effort to the productivity of the organization when the organization is giving them full support.

\subsubsection{Training and Performance}

The effects of training on performance in service companies. The aim of the study was to determine whether effort invested by service companies in employee training had an impact on their economic performance. Data was measured over a period of nine years. The findings supported that training activities are a positive influence on company performance Del Valle et al. (2009).

\subsubsection{Organizational Justice and Performance}

The organizational justice has been a very hot topic from a long time period till now and all level of researchers and also among the professional society. The organizational justice when achieved in its true sense, it may affect the employee performance, their commitment level in the organization and also their level of efforts towards achievement of their goals (Folger and Cropanzano, 1998).

\section{Research Objective}

$>$ To discover the factors that predicted job enrichment.

$>$ To understand the relationship between job enrichment and individual performance. 
Figure 1: Conceptual Framework

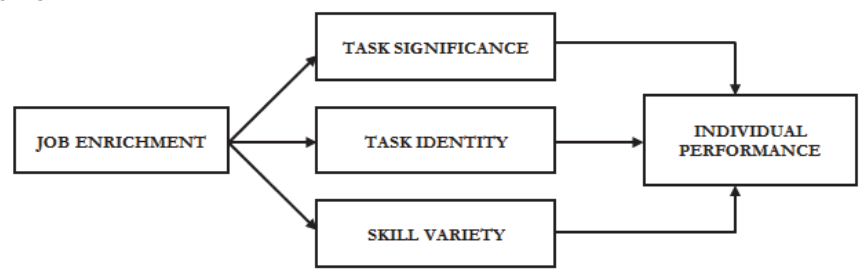

\section{Methodology}

The questionnaire used in the present study is adopted from the research studies of Bryan \& Locke (1967), Latham \& Baldes (1975), Latham \& Kinne (1974), Latham \& Yukl (1975), Ronan, Latham, \& Kinne (1973), Herzberg \& Frederick (1968), Myers (1970), Raja (1974). The questionnaire consisted of 13 items for job enrichment and 9 items for individual performance with closed ended questions on a five point Likert scale ranging from 5 - strongly agree to 1 - strongly disagree.

The responses were collected from the faculties in a private university. A stratified random sampling technique was used for the survey. The population of faculty of the private University is divided into small strata namely program chairs and division chairs and only these program chairs and division chairs is taken in to consideration for the study. The program chairs and division chairs of the University are enriched with more responsibility, power and authority for administrative purpose. This study was undertaken to analyse if job enrichment of the program chairs and division chairs enhanced their individual performance at work. To understand the relationship between job enrichment and individual performance a structured questionnaire was used to accumulate the data from various department faculties with direct contact. A total of 22 items was used for this survey excluding demographic characteristics. The sample size of the study is 56. The statistical package for social science (spss, version20) was used to analyze the data. The reliability test has been conducted to verify the internal consistency of the variables obtained in the sample. The cronbach's alpha is found to 0.902 , which is much higher than the minimum acceptable level suggested by (Nunally, 1978).

\section{Analysis and Discussion}

\subsection{Demographic Details of the Respondents}

Earlier researches had revealed that demographic variables had a vital role to play in any type of studies. Whatever the study may be, the demographic variables had a considerable impact on the dependent variable of the study. The researcher tried to understand demographic variables like age, sex and experience of the employees. Table 5.1.1 presents the frequency distribution of the respondents on each of the demographic variables.

Table 5.1.1. Demographic Characteristics Of The Study Participants [N=56]

\begin{tabular}{|c|c|c|}
\hline Demographic Variables & Frequency & Percent [\%] \\
\hline Male & 28 & $50 \%$ \\
\hline Female & 28 & $50 \%$ \\
\hline & \multicolumn{2}{|c|}{ Gender } \\
\hline $1-2$ years & 2 & $3.6 \%$ \\
\hline $2-4$ years & 4 & $7.1 \%$ \\
\hline $4-6$ years & 3 & $5.4 \%$ \\
\hline $6-8$ years & 11 & $98.6 \%$ \\
\hline 8-10 years & 36 & $64.3 \%$ \\
\hline 20-25 years & 0 & $0 \%$ \\
\hline 26-30 years & 4 & $7.1 \%$ \\
\hline 31-35 years & 29 & $51.8 \%$ \\
\hline 36-40 years & 17 & $30.4 \%$ \\
\hline 41-45 years & 6 & $10.7 \%$ \\
\hline
\end{tabular}


From 56 respondents, $28(50 \%)$ are male and $28(50 \%)$ are female respondents. The sample is representative of all age groups. Majority of the respondents (29\%) are of the age group between 31-35 years. When experience of the respondents is considered it is understood from the table above that nearly (64.3\%) of the respondents has between 8 10 years of experience. Thus it is clear that the study has generated responses from varied range of respondents adequately representing the diversity of the total population of the selected education institution.

\subsection{Scale Reliability}

The reliability of the scale is tested and the alpha value obtained is 0.902 . This value is higher than the acceptable (Table 5.1.1) lower limit of 0.6 according to Nunnally, J.C (1978). Being satisfied with the reliability of the instrument, the researcher carried out item to total item correlation to identify and remove any item that deviated in value. This process was repeated until it was made sure that there will not be any more improvement in the alpha value, by removing any item.

Table 5.2.1. Reliability Analysis - Scale (Alpha)

\begin{tabular}{|c|c|}
\hline \multicolumn{2}{|c|}{ Reliability Coefficients } \\
\hline $\mathrm{N}$ of Cases $=56$ & No. of Items $=22$ \\
\hline & Alpha $=.902$ \\
\hline
\end{tabular}

Table 5.2.2. Reliability Analysis - Scale (Alpha)

\begin{tabular}{|c|c|c|c|c|}
\hline \multicolumn{5}{|c|}{ Item-Total Item Variance } \\
\hline & Mean & SD & $\begin{array}{l}\text { Corrected Item- } \\
\text { Total Correlation }\end{array}$ & $\begin{array}{l}\text { Alpha if item } \\
\text { deleted }\end{array}$ \\
\hline I have the skills and abilities to do more work & 4.73 & .447 & 0.10 & .904 \\
\hline Opportunity is given by the institution to use my skills & 4.43 & .806 & 0.31 & .902 \\
\hline $\begin{array}{l}\text { I have adequate information and knowledge which enables me to } \\
\text { do my job well }\end{array}$ & 4.50 & 603 & 0.25 & .902 \\
\hline $\begin{array}{l}\text { The amount of work I am expected to do in my job is reasonable } \\
\text { for me }\end{array}$ & 4.07 & .783 & 0.45 & .899 \\
\hline $\begin{array}{l}\text { The amount of work I am expected to do in my job is reasonable } \\
\text { to the institution }\end{array}$ & 4.00 & .837 & 0.58 & .896 \\
\hline Motivation is important to do work more effectively & 4.55 & .685 & 0.16 & .904 \\
\hline Departments has good priorities and direction for employees & 3.64 & .943 & 0.48 & .898 \\
\hline My success at work is appreciated by my colleagues & 3.48 & .953 & 0.58 & .896 \\
\hline $\begin{array}{l}\text { Opportunity is given by the institution to complete my entire tasks } \\
\text { on my own }\end{array}$ & 3.95 & .923 & 0.58 & .896 \\
\hline $\begin{array}{l}\text { When I have a problem at work, my colleagues help me with } \\
\text { solutions }\end{array}$ & 3.61 & .947 & 0.31 & .903 \\
\hline My institution really cares about my well-being & 3.98 & 1.000 & 0.55 & .896 \\
\hline My institution strongly considers my goals and values & 4.14 & .862 & 0.57 & .896 \\
\hline My institution is willing to help me, when I need a special favour & 4.13 & .955 & 0.60 & .895 \\
\hline I am recognized fairly by my institution & 3.88 & .854 & 0.72 & .892 \\
\hline My personal milestones are recognized by my institute & 3.80 & .818 & 0.77 & .891 \\
\hline My institution, recognizes the hard work of employees & 3.86 & 1.086 & 0.66 & .893 \\
\hline $\begin{array}{l}\text { My institution addresses life problems that hinders employees } \\
\text { performance }\end{array}$ & 3.68 & .974 & 0.54 & .897 \\
\hline $\begin{array}{l}\text { My institution addresses life problems that hinders employees } \\
\text { performance }\end{array}$ & 3.66 & .959 & 0.58 & .896 \\
\hline I am motivated to do my best for this institution & 4.13 & .740 & 0.67 & .894 \\
\hline I am enable to engage myself in any recreational activities & 3.75 & .958 & 0.45 & .899 \\
\hline My personal objectives match with institutional objectives & 3.73 & .842 & 0.54 & .897 \\
\hline I am rewarded according to AICTE/UGC standards & 3.96 & 1.008 & 0.59 & .895 \\
\hline Alpha & & & .902 & \\
\hline
\end{tabular}


Table 5.2.3. Reliability Statistics

\begin{tabular}{|c|c|c|}
\hline Cronbach's Alpha & Cronbach's Alpha Based on Standardized Items & N of Items \\
\hline .908 & .907 & 19 \\
\hline
\end{tabular}

Finally from 22 items only 3 deviating items was removed and the rest 19 items with an increased alpha value of .908 after item to item correlation was retained by the researcher which is summarized in Table.5.2.3

\subsection{Factor Analysis}

After deciding on the 10 independent items that correlate well with each other, exploratory factor analysis was carried out to identify the underlying interventions for job enrichment. But before proceeding on with factor analysis, few preliminary tests like Kaiser Meyer-Olkin (KMO) measure of Sampling Adequacy (.74) and Bartlett's Test of Sphericity was done to justify that factor analysis is an appropriate tool for the present study.

In KMO test a value closer to 1 indicates that the patterns of correlations are relatively compact and so the factor analysis should yield distinct and reliable factors. Kaiser (1974) recommends accepting values greater than 0.5 as acceptable. To make certain that a given item represented the construct in the underlying factor, a factor loading of .40 was used as the minimum cutoff (Youndt et al, 1996). The result of the factor analysis is provided in Table.5.3.1. Three Factors were derived with Eigen values greater than one and total variance of 71 percent was explained

\section{Table 5.3.1. Factor Analysis - Rotated Component Matrix}

\begin{tabular}{|l|c|c|c|}
\hline \multirow{2}{*}{ Variables } & \multicolumn{2}{|c|}{ Component } \\
\cline { 2 - 3 } & $\mathbf{1}$ & $\mathbf{2}$ & $\mathbf{3}$ \\
\hline Factor - 1 Task Significance & & & \\
\hline The amount of work I am expected to do in my job is reasonable to the institution & .852 & & \\
\hline My success at work is appreciated by my colleagues & .788 & & \\
\hline Opportunity is given by the institution to complete my entire tasks on my own & .768 & & \\
\hline Departments has good priorities and direction for employees & .687 & & \\
\hline Factor 2 - Task identity & & & \\
\hline My institution strongly considers my goals and values & & .855 & \\
\hline My institution really cares about my well-being & & .880 & \\
\hline My institution is willing to help me, when I need a special favour & & .827 & \\
\hline Factor 3 - Skill Variety & & & \\
\hline Opportunity is given by the institution to use my skills & & .836 \\
\hline I have adequate information and knowledge which enables me to do my job well & & & .810 \\
\hline The amount of work I am expected to do in my job is reasonable for me & & .625 \\
\hline Kaiser-Meyer-Olkin Measure of Sample Adequacy & & .74 \\
\hline Bartlett's Test of Sphericity & & 235.840 \\
\hline Significance & & .000 \\
\hline
\end{tabular}

Table 5.3.2. Factor Mean And Alpha

\begin{tabular}{|c|l|c|c|c|}
\hline No. & Factor & Mean Score & Eigen Value & Cronbach Alpha \\
\hline 1 & Task Significance & 3.7 & 4.0 & .81 \\
\hline 2 & Task Identity & 4.0 & 4.1 & .87 \\
\hline 3 & Skill Variety & 4.3 & 4.5 & .68 \\
\hline
\end{tabular}

Four items like Expectation to Institution, Priorities and Direction, Colleagues Appreciation and Task Completion are loaded under factor one with factor loadings ranging from .85 to .68. The Alpha Value for the first factor is .81 and the factor mean score is 3.7 (Table.5.3.2) which indicated a strong level of agreement among the respondents for Factor one. The four items loaded under factor one emphasize that the work of employees directly contributed to the Institution. Hence Factor One was named as Task significance.

Three items like Well Being, Goal and Values and Special Favor were loaded under Factor two with loading 
ranging from .85 to .82 . The Alpha Value for the second factor is .87 and the factor mean score is 4.0 (Table.5.3.2) which indicated a strong level of agreement among the respondents for Factor two. The items loaded under Factor two emphasized that the Institution facilitated the employees for job enrichment. Hence Factor two is named as Task Identity.

Three items Opportunity, Job Well, Expectation for Me such as were loaded under Factor Three with loading ranging from .83 to .62. The Alpha Value for the third factor is .68 and the factor mean score is 4.3 (Table.5.3.2) which indicated very strong level of agreement among the respondents for Factor three. The three items loaded under this factor indicated that the institution provided them opportunity to use and improve their skills. Hence Factor Three was named as Skill Variety.

\subsection{Relationship Between Demographic Variables And Individual Performance}

$\mathrm{H} 1$. There is no significant relationship between various demographic variables and Individual Performance.

$\mathrm{H} 2$ - There is no association between job enrichment and individual performance

Table 5.4.1. Relationship Between Demographic Variables And Individual Performance

\begin{tabular}{|c|c|c|c|c|c|c|}
\hline \multicolumn{7}{|c|}{ ANOVA } \\
\hline & & Sum of Squares & $\mathrm{Df}$ & Mean Square & $F$ & Sig. \\
\hline \multirow{3}{*}{ Gender } & Between Groups & .170 & 1 & 0.170 & \multirow{3}{*}{.167} & \multirow{3}{*}{.684} \\
\hline & Within Groups & 54.830 & 54 & 1.015 & & \\
\hline & Total & 55.000 & 55 & & & \\
\hline \multirow{3}{*}{ Age } & Between Groups & .331 & 1 & 0.331 & \multirow{3}{*}{.327} & \multirow{3}{*}{0.57} \\
\hline & Within Groups & 54.669 & 54 & 1.012 & & \\
\hline & Total & 55.000 & 55 & & & \\
\hline \multirow{3}{*}{ Experience } & Between Groups & 1.729 & 1 & 1.729 & \multirow{3}{*}{1.752} & \multirow{3}{*}{191} \\
\hline & Within Groups & 53.271 & 54 & .987 & & \\
\hline & Total & 55.000 & 55 & & & \\
\hline
\end{tabular}

It is inferred from the table above (Table.7), the significance value is greater than .05 for all the demographic variables gender $(p=.18)$, age $(p=.57)$ and experience $(p=.19)$. This indicated that there is no significant difference between age, gender, experience and individual performance.

\subsubsection{Job Enrichment Model}

After checking out the positive and strong relationship of job enrichment with individual performance and multiple regression model for individual performance in education institution was developed with various job enrichment practices like as task significance, task identity and skill variety predictors with the hypothesis that each of the predictor would have differing prediction ability on individual performance.

\subsubsection{Job Enrichment Model And Individual Performance}

A multiple regression model for building Individual Performance in education institution was developed with various Job Enrichment Practices like as task significance, task identity and skill variety predictors with the hypothesis that each of the predictor would have differing prediction ability on individual performance.

The factors influencing individual performance is expected to have positive magnitude and the theoretical expectation is portrayed in the model with positive contribution by the various factors.

The proposed regression model is given below:

Individual performance $Y=a+b 1 X 1+b 2 X 2+b 3 X 3$

Where,

X1 - Task significance

$\mathrm{X} 2$ - Task identity

$\mathrm{X} 3$ - skill variety

a - constant 


\subsection{Model Summary}

The coefficient of determination (Table) $\mathrm{R}^{2}$ was compared to determine percentage variation in the dependent variable. $\mathrm{F}$ value was to compute the significance of $\mathrm{R}^{2}$ with F-distribution at $5 \%$ level of significance. The model is found fit on significance (.000) of independent variable proving individual performance depends on Job enrichment practices like task significance, task identity and skill variety.

The prediction ability of the model is expressed by $\mathrm{R}$ square which was .611 whereby $61 \%$ (Table.5.5.1), of the variance in individual performance was explained by Job Enrichment practices like task significance, task identity and skill variety with F-value 27.184 (Table.5.5.2) at .000 level of significance.

Table 5.5.1. Multiple Regression Analysis For Individual Performance And Job Enrichment Variables As Predictors

Model Summary

\begin{tabular}{|c|c|c|c|c|}
\hline Model & R & R Square & Adjusted R Square & Std. Error of the Estimate \\
\hline 1 & 0.781 & 0.611 & 0.588 & 0.64173657 \\
\hline
\end{tabular}

a. Predictors: (Constant), task significance, task identity and skill variety

Table 5.5.2. ANOVA (B)

\begin{tabular}{|c|c|c|c|c|c|c|}
\hline Model & & Sum of Squares & Df & Mean Square & F & Sig. \\
\hline 1 & Regression & 33.585 & 3 & 11.195 & 27.184 & $.000(\mathrm{a})$ \\
\hline & Residual & 21.415 & 52 & .412 & & \\
\hline & Total & 55.00 & 55 & & & \\
\hline
\end{tabular}

a. Predictors: (Constant), task significance, task identity and skill variety

b. Dependent Variable: Individual Performance

c.

In predicting the development of individual performance (Table.5.5.3), in education institution it is found that task identity is found to be the most important variable $(\beta=0.773, t=8.932$ followed by task significance $(\beta 0.105, t=1.210)$ and skill variety $(\beta=0.048, t=0.559)$.

Table 5.5.3. Association Of Job Enrichment And Individual Performance

Coefficients

\begin{tabular}{|c|c|c|c|c|c|c|}
\hline \multirow{2}{*}{ Model } & & \multicolumn{2}{|c|}{ Unstandardized Coefficients } & \multirow{2}{*}{$\frac{\text { Standardized Coefficients }}{\text { Beta }}$} & \multirow{2}{*}{$\mathrm{T}$} & \multirow{2}{*}{ Sig. } \\
\hline & & B & Std. Error & & & \\
\hline \multirow{4}{*}{1} & (Constant) & 1.725 & .086 & & .000 & 1.000 \\
\hline & Task Significance & .105 & .087 & .105 & 1.210 & .232 \\
\hline & Task Identity & .773 & .087 & .773 & 8.932 & .000 \\
\hline & Skill Variety & .048 & .087 & .048 & .559 & .579 \\
\hline
\end{tabular}

a. Dependent Variable: Individual Performance

Regression Equation

Individual Performance $=1.725+.105$ (task significance) +.773 (task identity) +.048 (skill variety)

The study revealed individual performance is influenced by job enrichment. Task identity helps the employees to meet the standard of work and to cope up with the changes in the Institution. With these characteristics of task identity employee becomes more valuable for an Institution.

\section{Conclusion}

The finding of this study has proved a relationship between Job enrichment and Individual performance. Among job enrichment factors Task Identity contributes more towards enhancing the performance of individuals. Hence academic institution should focus on giving academic freedom to their faculty. This would enable them to utilize their skills and ability and space should be provided for the faculty to complete their, task on their own. 
The study also certified that demographic variables like whether male or female, nor experience and gender make any impact on the performance of employees.

\section{References}

Bryan, J. F., and E. A. Locke. (1967) "Goal Setting as a Means of Increasing Motivation," Journal of Applied Psychology, Vol. 51, pp.274-277

Colarelli, S.M., Dean, R.M., \& Konstans, C. (1987), "Comparative Effects of Personal and Situational Influences on Job Outcomes of New Professionals," Journal of Applied Psychology, Vol.72, pp.558-566

Collins, D.C. and Raubolt, R.R. (1975). A study of employee resistance to job enrichment. Personnel Journal (pre-1986), April 1975, Vol.54 (4), pp.232-248.

Del Valle, I.D., Castillo, M.A.S. and Rodriguez-Duarte, A. (2009). The effects of training on performance in service companies: A data panel study. International Journal of Manpower, Vol.39 (4), pp.393-407

Eisenberger, R., Fasolo, P., \& Davis-LaMastro, V. (1990), "Perceived Organisational Support and Employee Diligence, Commitment, and Innovation," Journal of Applied Psychology, Vol.75, pp.51-59

Folger, R.G, \& Cropanzano, R. (1998), Organisational Justice and Human Resource Management, Sage, Beverly Hills, CA

Hackman J. R. \& Oldham (1975): Development of the Job Diagnostic Survey, Journal of Applied Psychology Vol.60 (2), pp. 159-170

Hart, D.E., \& Willower, DJ. (1994), "Principals' Organisational Commitment and School Environmental Robustness," Journal of Educational Research, Vol.87, pp.174-179

Herzberg, Frederick. (1968) "One More Time: How Do You Motivate Employees?" Harvard Business Review, Vol. 46, pp.53-62

Kaiser, H.F. (1974), An index of factorial simplicity, Pschometrika, Vol.39, pp.31-36

Kaplan, H.R., Tausky, C. and Bolaria, B.S. (1969). Job enrichment. Personnel Journal (pre-1986), Vol.48 (10), pp.791-798

King-Taylor, L. (1977). Job enrichment and motivation. Education + Training, Vol.19 (10), pp.295-300

Latham, G. P., and G. A. Yukl. (1975) "Assigned Versus Partici-pative Goal Setting with Educated and and Uneducated Wood Workers," Journal of Applied Psychology, Vol. 60, pp.299-302.

Latham, G. P., and S. B. Kinne. (1974) "Improving Job Perform-ance Through Training in Goal Setting," Journal of Applied Psychology, Vol. 59, pp.187-191

Latham, G. P., and j. J. Baldes. (1975) "The 'Practical Signifi-cance' of Locke's Theory of Goal Setting," Journal to Ap-plied Psychology, Vol. 60, pp.122-124

McLean, A.J. and Sims, D.B.P. (1978). Job enrichment from theoretical poverty: The state of the art and directions for further work. Personnel Review, Vol.7 (2), pp.5-10

Myers, M. S. Every Employee A Manager (New York: McGraw-Hill, 1970)

Norton, S.D. and Massengill, D. and Schneider, H.L. (1979). Is job enrichment a success or a failure? Human Resource Management, Vol.18 (4), pp.28-37

Nunnally, J.C., (1978), Psychometric Theory (2nd ed.), New York, McGraw-Hill

Raia, A. P. Management By Objectives (Glenview, III.: Scott, Foresman, 1974)

Ronan, W. W., G. P. Latham, and S. B. Kinne. (1973) "The Effects of Goal Setting and Supervision on Worker Behavior in an Industrial Situation," Journal of Applied Psychology, Vol. 57, pp.302-307

Saleem, S., Shaheen, W.A. and Saleem, R. (2012). The impact of job enrichment and job enlargement on employee satisfaction keeping employee performance as intervening variable: A correlation study from Pakistan Kuwait Chapter of Arabian Journal of Business and Management Review, Vol.1(9), pp.145-165

Uneducated Wood Workers, (1975) " Journal of Applied Psychology, Vol. 60, pp.299-302

Walsh, B. (1974). A practical approach to job enrichment. Industrial and Commercial Training, Vol.6 (4), pp.185-187

Werther, W.B. (1975). Beyond job enrichment to employment enrichment. Personal Journal (pre-1986), Vol.54 (8), pp.438-442

Youndt et al., (1996), Human resource management, manufacturing strategy, and firm performance, Academy of Management Journal, Vol.39, pp.836-866 